\title{
The Impact of School's Resource Center on Teaching and Learning Process
}

\author{
Hamidah, Y., Norasibah, A. J., Abd Razak, A. Z. A., Yunus, NKY* \\ Faculty of Management and Economics, Univerisiti Pendidikan Sultan Idris \\ 35900 Tanjong Malim, Perak, Malaysia \\ *nkamal@fpe.upsi.edu.my
}

\begin{abstract}
The general objective of this study is to examine the impact of School's Resource Center (SRC) on teaching and learning process among secondary school teachers. The specific objectives are; to identify factors influencing the utilization of the SRC and the problems associated with it. In general, 100 school teachers from three secondary schools in Tanjung Malim, Perak were selected as our respondents. Sample selection was made based on purposive sampling and the data obtained were processed by using quantitative method. The results obtained reported that, on average teachers used the SRC twice a week. The reasons for the usage are; to make use the printing and non-printing media available at the SRC, and to participate in various activities and programs organized at the center. In terms of problems, there was no indication on the presence of any serious problem except the SRC should sustain its resources. In particular, the SRC must continuously upgrade the collections of printing and non-printing media with most updated and contemporary issues. Apart of that, the SRC must make available technical assistant(s) to help out the SRC users (students and teachers) anytime needed. In terms of effect, the utilization of SRC encourages group study among students and this approach not only helped to improve students understanding and to inspire their reading interest, but also offered motivation to students in understanding the content of a particular subject better.
\end{abstract}

Keywords: School's Resource Center (SRC), Utilization, Secondary School, Teachers, Teaching and Learning

\section{Introduction}

In line with change in era, Malaysia's education system reacts by moving very fast through its diverse policy implementation. In the mission to cope with the change, the fundamental transformation that must take place before any final objective can be achieved is the change in teachers' attitude and quality. Teachers must be versatile, flexible and able to adjust consistent with change in time. One of the latest changes in the local education system is the establishment of School's Resource Center (SRC). The establishment of such knowledge center is considered as important and necessary as it benefits not only the teachers but also the students. In order to divert from a traditional to an up-to-date teaching style, teachers must learn how to teach by using the materials offered at school's resource center. The School Resource Center (SRC) not only functions as a place which has collections of teaching assistance kits, but also provides additional information and prepares various assistance and services for teaching and learning (T\&L) activities, researches, and recreations. This type of teaching approach helps students develop information detection skill which will in turn help them solve any type of learning problems and encourage lifetime knowledge. In other word, the utilization of SRC is envisaged as capable to improve students' academic performance and also to enhance teachers' professionalism in Teaching and Learning (T\&L) activities.

A study by Padlon (2004) stated that the SRC is part of global information network which can enhance the degree of information availability and assist fast and accurate data information transformation. Teachers must utilize SRC efficiently and treat the SRC as the heart of the teaching and learning process. In other word, teachers play very important role in the following aspects. First, assisting the students in how to use SRC in the knowledge, data and information gathering; second, provide guidance in systematic application of the knowledge in the learning process; and third, to foster reading interest among students. Other than SRC, the center is also known as Knowledge Resource Center, Learning Center, Electronic Resource Center, and Education Resource Center, which all share the same property of a place to obtain knowledge. However, students in general, still facing problems when pursuing their studies at a higher level, where they still cannot integrate the knowledge that they have learned through the usage of library (Norhafizah, 2008). According to 
the same study, the author makes an assertion that, at current, school community's level of readiness is still low in the integration and application of resources in the implementation of school curriculum. Schools should organize more programs that encourage frequent usage of the SRC.

\section{The Use of School's Resource Center (SRC)}

The use of SRC, in general, is defined as the usage of any tool, service, material or area at the SRC by students and teachers. However, Robiah \& Noraffandy (2008) summarize the use of SRC as a searching, reading and referring processes, in the effort to get information for the purpose of learning and knowledge. In other study by Har (1990), the use of SRC is referring to the use of services and facilities offered at SRC to assist and to strengthen the teaching and learning process. This statement is supported by Sulaiman (1993) who in the opinion that, using the SRC means to master the skill in using indices and abstracts, and the application of media electronics tools such as projector, slides, software's and others.

The degree of SRC usage can also be assessed in terms of number of visits made by students and teachers within specific time. Other than that, it can also be measured through the following methods; (i) how frequent the material is used, (ii) the amount or number of sources borrowed and (iii) activities done while using SRC. Other than the previous findings, a study by Robiah \& Noraffandy (2008) are in view that, SRC is an organization that compiles and disseminate all learning and teaching material. It was done according to the levels of students and teachers that are using it, which includes life materials, non-life materials, printed or non-printed. In order to access these materials, students need to develop skills in identifying important information. This approach not only nurture students' skill in information seeking but also enhances their quality of learning. The same study also stressed that, the ability to identified information is an important pre-requisite in implementing learning and teaching according to the SRC approach.

Robiah \& Noraffandy (2008) further emphasized that; the SRC should be interpreted in a wider and broader perspective so that the whole aspect of learning and teaching can be enhanced with active involvement and participation from the teachers and students. Therefore, the efforts to use SRC in enhancing teaching and learning would be fruitful. This research, in general studies the impact of SRC usage on teaching and learning process. In particular, it looked at how teachers used SRC, factors influencing the usage, problems and the implication of SRC usage among the teachers. The research questions for this study are:

- What are the factors that influence the SRC usage among teachers at secondary school?

- What are the problems associated with SRC usage among teachers at secondary school?

- What are the effects of SRC usage among students?

We are in view that the findings of this study provide useful information to schools' operators on the significance and efficiency of the SRC. Moreover, this information may provide useful guidance to schools' operators on future decision relating to SRC improvements and developments, with the end objective to enhance teachers' teaching and students' learning processes.

\section{Research Methodology}

This research used quantitative method of analysis. Data were collected through questionnaire distribution to teachers at three secondary schools in the district of Tanjung Malim. Approximately 100 respondents, who were comprised of 40 percent male teachers and 60 percent female teachers, were chosen for this study. In particular, 71 percent of them were graduates teachers who had a minimum teaching experience of five years. The respondents were chosen by using purposive sampling at schools located in Tanjung Malim, Perak, Malaysia.

The data were collected by using a set of four Likert scale point questionnaires which comprised of three sections; A, B, C. Section A is comprised of questions relating to respondent's profile; while section B, focuses on questions related to the usage of the SRC; and finally section $C$, include questions which focused on factors that influence the usage of SRC, problems and implication of the SRC usage. A pilot study was conducted and the reliability values for the three research variables were as follows: usage factors, 0.6 ; problems variables, 0.7 ; and implication factors, 0.9 . 


\section{Results and Discussion}

The overall outcome of this study documented the following results. Approximately 32 percent of the teachers used SRC twice a week and 30 percent used SRC more often and only 19 percent used SRC more than twice a week. The SRC usage was at highest during "recess period" (41\%), followed by "the time stipulated in the time-table" (28\%), and finally "during other times" (17\%). Among the favorite reasons for using SRC was; "doing assignments", (32\%), "discussions with other teachers" (28\%), "light reading such as magazines and newspapers" (26\%) and finally "for other reasons" (14\%).

Factors Influencing SRC Usage: The input from the respondents stated that the non-printed materials that were available in the SRC such as cassette, multimedia CDs, models, globe, toys, disks, video cassette and others were very helpful in enhancing the teachers' knowledge (mean=3.28). The teachers also made an assertion that the SRC materials enhance their teachings delivery, which made teaching to become more efficient and interesting (mean=3.16), and the variety of activities at SRC also provide another explanation why teachers used SRC (mean=3.11).

Table 1: Factors that Influence the Usage of SRC

\begin{tabular}{lcc}
\hline Item & Mean & S.D. \\
\hline Are the materials listed below in the SRC helps to increase the teachers' knowledge? & & \\
i. Printed materials; Books, magazines, news papers, photo pictures and others & 3.20 & 0.55 \\
ii. Non-printed materials; Cassette, Multimedia CDs, Models, Globe, toys, disks, video & 3.28 & 0.81 \\
$\quad$ tapes and others & 3.16 & 0.67 \\
The usage of materials at SRC enables teaching to be more interesting. & 3.09 & 0.47 \\
The usage materials at SRC in the teaching process enable me to understand the & 3.16 & 1.23 \\
subjects that I teach. & 3.11 & 0.71 \\
I always use teaching aids provided by SRC during teaching and learning sessions. & & \\
The activities organized by SRC such as NILAM program, reading contests, book fairs, & & \\
excursions and workshops encourage me to use SRC. & 2.95 & 0.50 \\
\hline SRC is a change agent for the teachers. & & \\
\hline
\end{tabular}

Problems Associated With the Usage of School Resource Center: Based on the findings, teachers think that the reference and collections in the SRC should be improved in a number of ways. Firstly, improvement should be made in terms of number of reference books for reference and borrowing (mean=2.4); secondly, collections of reference materials should be of the latest edition (mean=2.45); thirdly, the SRC should proved a technician who are skillful to provide technical assistance whenever needed (mean=2.87); and finally, an improvement in terms of strategic location of the SRC.

Table 2: Problems Associated with the Usage of the SRC

\begin{tabular}{lcc}
\hline Item & Mean & SD \\
\hline The reference and collection in the SRC is adequate for referencing and & 2.40 & 0.67 \\
borrowing & & \\
Reference materials in the SRC is the latest edition & 2.45 & 0.61 \\
I used to SRC because it is equipped with & 3.06 & 0.71 \\
1.air-conditioner & & \\
2. the arrangement of furniture are tidy, clean and attractive & 3.03 & 0.72 \\
The SRC is strategically located & 2.88 & 0.76 \\
The teachers are skillful in using the SRC materials and equipment & 2.95 & 0.74 \\
1.overhead projector, slides and film strips & & \\
2.using software, audio materials, tv.vcr and computer & 3.15 & 0.64 \\
3. search system (online public access cataloging) & 2.65 & 0.80 \\
The SRC's operating hours is suitable & 3.16 & 0.55 \\
Teachers are getting technical helps while using media equipment at the SRC. & 2.87 & 0.68 \\
Teachers' heavy workloads prevent them from using the SRC. & 2.90 & 0.67 \\
\hline
\end{tabular}


The Effect of SRC on Students' Learning: The overall results were displayed in Table 3. The outcome of the analysis provides indication that; teachers were in view that the usage of SRC in their teaching process is capable to improve students' learning in the following ways. Firstly, it encouraged students group learning activity (min=3.28), secondly, it enhance students' understanding on facts delivered and discussed $(\mathrm{min}=3.22)$, thirdly, it nurtured the interest in students' reading habits $(\mathrm{min}=3.11)$, and gave motivations to the students in understanding the content of a course (min=3.11).

Based on the findings in this section, we may conclude that; teaching with the usage of SRC, developed students' skill and creativity and finally enhance students' learning process. The finding of this study has connection with Maier (1970) who figured that knowledge and skills of acquiring information given to students before they conduct their library search will help them to use the school resource centre (or SRC) effectively. It is important to train the students on how to make use the school's SRC so that the SRC could be used to the fullest. Therefore, this study proposed that students and teachers should attend courses on how to use information system tools and how to acquire information in SRC such as OPAC to make the search for books and other reference materials. This will make searching process to become easier and faster. According to William and Wavell (2001) the impact of SRC on students' learning includes improving the library skills, information handling skills, ICT skills, study skills, reading skills, and the ability to apply skills or knowledge in different context.

Table 3: The effect of SRC on Students' Learning

\begin{tabular}{|c|c|c|}
\hline Item & Mean & S.D. \\
\hline $\begin{array}{l}\text { The materials used in the teaching process at the SRC are attractive and capable to } \\
\text { enhance students' understanding. }\end{array}$ & 3.22 & 0.52 \\
\hline At SRC, the students involved actively while teaching session is going on. & 2.96 & 0.49 \\
\hline Teaching at the SRC could cultivate the reading interest among students. . & 3.11 & 0.49 \\
\hline $\begin{array}{l}\text { Teaching activities at SRC gives motivation to the students to understand the content of a } \\
\text { subject. } \\
\text { i. Games: Sahibba, Chess, Scabble. }\end{array}$ & 2.96 & 0.69 \\
\hline ii. Film presentation, TV and radio (education) & 3.11 & 0.60 \\
\hline iii. the usage of models, globe and replica & 3.12 & 0.54 \\
\hline Activities at SRC encourage group learning behavior among students & 3.28 & 0.49 \\
\hline $\begin{array}{l}\text { i. The usage of materials at SRC makes students to become more creative. i.e. : TV and } \\
\text { Radio (education) }\end{array}$ & 3.24 & 0.53 \\
\hline ii. 3 dimensional materials: i.e.: Replica, diagram, globe, map, charts, and games. & 3.23 & 0.58 \\
\hline iii. Computer materials: i.e.: diskette, $\mathrm{CD}$ interactive & 3.23 & 0.53 \\
\hline iv. Audio materials: i.e.: cassette, CDs & 3.19 & 0.54 \\
\hline
\end{tabular}

In general, majority of the respondents had relatively agreed that, the usage of SRC had helped them gained more knowledge and also had made their teaching more interesting and gave motivation to the students to learn better. This statement is consistent with the study done by Rokiah (1999, in Robiah \& Noraffandy, 2008), who claimed that, teaching and learning can be more effective by using technology, which is the latest pedagogy method, which include the usage of variety of multimedia materials. Research carried out by Ahmad (2004) shows that SRC played an important role in supporting the teaching and learning process especially in the integration of technology.

However, the respondents also emphasize that; the usage level of SRC could be improved if several problems highlighted earlier were taken care of. For example, the number of visits to SRC amongst teachers (and students) would increase if it offers many alternatives of resources, either in the form of media or printing materials, and contain most contemporary information and relevant body of knowledge. Other than that, the SRC should be equipped with user friendly instruments or teaching and learning aids, plus an improved service or assistance by a skilled technician. The number of visits to SRC can also be improved through incentive systems develop by the school or teachers, for example through the enrichment of the NILAM 
reading program, by organizing reading competition, book fair, and workshops. The programs highlighted above were consistent with the findings of Choon (2006) who figured that, the implementation of such programs by or at SRC records higher turn up rate. The higher turn-up rate provides an index not only on the success rate of the program but also implied an attraction rate of the SRC to the teachers and the students. Therefore, school principals should encourage more teachers to use the SRC. They should encourage and motivate students to use the SRC as well.

\section{Conclusion}

The research aimed to investigate the usage of school SRC by teachers (and students) in schools. As a general conclusion, we may conclude that the SRC should be improved to ensure effective usage which would enhance teaching and learning process. As one of the alternatives, we proposed to make it compulsory for media teachers or staff responsible in the management of the SRC to attend courses associated with SRC operations and management to ensure efficient operations of the SRC, and the people (students and teachers) who used the SRC could enjoy optimum benefit out of it. For further research, it is recommended that research should be conducted in wider scope with larger respondents. Perhaps by employing better or different methodology could give be outstanding results.

\section{References}

Ahmad, S. (2004). The role of the school resource center in technology integration in teaching and learning in selected secondary schools. Unpublished Master's Thesis, University of Malaya.

Abd. Rahman, H. (1993). Effective information skills using the school library resource centre. Wawasan Journal, 8(1), 36-47.

Choon, T. P. (2006). Strategic planning for resource centre. Retrieved April 20, 2011, from http://www.docstoc.com/docs/21532380/perancangan-strategik-pusat-sumber-sekolah.

Har, S. C. (1990). An investigation on the perception of students on the use of school library resource centre in General Paper. Unpublished Master's Thesis, National University of Malaysia.

Maier, N. F. (1970). Problem solving and creativity in individuals and groups. London: Brooks / Cole. Mancall, J. C. \& M.C. Prott.

Norhafizah, M. (2008). The use of library resource centre among teachers in Kota Tinggi, Johor secondary schools. Unpublished Master's Thesis, University Technology Malaysia.

Padlon, A. R. (2004). The role of school library resource centre in encouraging reading habit under Nilam Program. Retrieved April 20, 2011, from http://dspace.fsktm.um.edu.mybitstream /1812/678/1/Peranan\%20pusat\%20sumber\%20 sekolah \%20_PSS_\%20salam.pdf.

Robiah, Y., \& Noraffandy, Y. (2008). The use of school library resource centre (LMC): Factors, effects and problems. Unpublished Master's Thesis, University Technology Malaysia.

School Library Resource centre self-evaluation model for secondary schools. (2004). Retrieved April 20, 2011, from http://www.informat.org/schoollibraries/downloads /ssecmplt.doc.

Sulaiman, A. W. (1993). Perception of form 4 on factors that affects the use of school library resource centre in Bentong, Pahang Darul Makmur. Unpublished PhD's Thesis, National University of Malaysia, Bangi.

Williams, D., \& Wavell, C. (2001). The impact of the school library resource centre on learning. Report on research conducted for Resource. The Council for Museums, Archives and Libraries Library and Information Commission. Research Report 112. Retrieved April 20, 2011, from The Robert Gordon University: http://www.google.com.my/. 